\title{
Towards an Operations Strategy for Product-Centric Servitization
}

\author{
Tim Baines, Howard Lightfoot, Joe Peppard, Mark Johnson, Ashutosh Tiwari \& \\ Essam Shehab.
}

Cranfield Innovative Manufacturing Research Centre, Cranfield University, UK

$\&$

Morgan Swink,

Eli Broad College of Business, Michigan State University, USA

\begin{abstract}
Purpose: This paper presents a framework that will help manufacturing firms to configure their internal production and support operations to enable effective and efficient delivery of products and their closely associated services.

Design/methodology/approach: First we establish the key definitions and literature sources directly associated with servitization of manufacturing. We then develop a theoretical framework that categorises the key characteristics of a manufacturer's operations strategy, this is populated using both evidence from the extant literature and empirical data.

Findings: The framework captures a set of operations principles, structures and processes which can guide a manufacturer in the delivery of product-centric servitized offering. These are illustrated and contrasted against operations that deliver purely product (production operations) and those which deliver purely services (services operations).

Limitations/implications: The work is based on a review of the literature supported by data collected from an exploratory case study. Whilst it provides an essential platform, further research will be needed to validate our framework.

Originality: The principal contribution of this paper is a framework which captures the key characteristics of operations for product-centric servitized manufacture.
\end{abstract}

Keywords: Servitization, Product-service system, Service operations, Service marketing, Services science, Operations strategy 


\section{Introduction}

Servitization ${ }^{1}$ is now widely recognised as the process of creating value by adding services to products (Vandermerwe \& Rada, 1988). Since this term was first coined in the late 1980s it has been studied by scholars to understand the methods and implications of service-led competitive strategies for manufacturers (e.g. Wise \& Baumgartner, 1999; Oliva \& Kallenberg, 2003; Slack, 2005). During this same period there has been a similar growth in research on such related topics of Product-Service Systems (PSS) (Goedkoop, 1999; Mont, 2000; Meijkamp, 2000; Manzini \& Verzolli, 2003), Services Operations (Chase \& Apte, 2006) and Services-Science (Chesborough \& Spohrer, 2006). This increasing body of research indicates a growing interest in service-led competitive strategies by academia, business and government. One reason for this is the belief that a move towards servitization is a means to create value-adding capabilities that are distinctive, sustainable, and easier to defend from competition based in lower cost economies. Indeed, many governments see such moves downstream as key to competitiveness (e.g., Hewitt, 2002). As a consequence, more and more western manufacturers are seeking an ever increasing percentage of their revenues from services (Wise \& Baumgartner, 1999).

To succeed with servitization a manufacturer will require new guiding principles, structures and processes for their production and support operations (Oliva \& Kallenberg, 2003). These are likely to be different to those associated with traditional manufacture. Authors such as Voss (1992) and Chase (1989) suggest that there is a subtle and distinct mix of organisational structures and processes which are appropriate to a servitized manufacturer. In this paper, our particular interest is product-centric servitization. This is the term we give to the phenomena where a portfolio of services is directly coupled to a product offering. In other words, an integrated product and service offering where the product itself is central to the provision of an integrated set of services (e.g. maintenance, repair, and/or support). Examples include Xerox's move from selling printers and copiers to delivering 'Document Management' (www.consulting.xerox.com), and Thales's Training and Simulation business with 'pay as you train' (Mulholland, 2000). For traditional manufacturers providing these types of offerings into the marketplace necessitates the transformation of existing organisational structures and processes. This topic has yet to receive the detailed attention of researchers. Indeed, even contemporary management text books give insufficient treatment to the detailed integration of manufacture and services at the level of the configuration of internal resources to deliver the servitized offering (e.g. Heineke,\& Davis 2007).

The research reported in this paper therefore proposes a set of operations principles, structures and processes for the delivery of product-centric servitization. We have based these characteristics on an analysis and synthesis of the wider literature, supplemented with empirical data collected via an exploratory case study with a leading servitized manufacturer (section 3). To achieve this, our research programme has followed three steps. First, we establish the key definitions and literature sources that underpin the debate on servitization (section 1). In doing this we briefly revisited definitions of product, service and services. The second step was to develop a theoretical framework that categorises the key characteristics of differing forms of business operations (section 4). Finally, we populate this framework deductively, based on the existing literature, and informed by the case study data (section 5). Through this programme, we prepare a foundation onto which future studies can test, refine, and expand our understanding of how manufacturers need to change if they are to execute a servitization strategy.

\footnotetext{
${ }^{1}$ Servitization is often referred to as servicizing, particularly in United States. See White et al (1999) and Rothenberg (2007).
} 


\section{Background}

\subsection{Industrial context}

In the aerospace sector, engine manufacturers such as Rolls-Royce, General Electric and Pratt \& Whitney, all offer some form of performance-based contracts with commercial airlines in which their compensation is tied to product availability and the capability it delivers (e.g., hours flown). Rolls-Royce $(\mathrm{R}-\mathrm{R})$, in particular, have now registered trademarks for both 'Power by the Hour' and the more inclusive 'TotalCare' contracts. Such contracts provide the airline operator with fixed engine maintenance costs, over an extended period of time (e.g., ten years). In developing TotalCare, R-R is just one an example of a manufacturer that has adopted a product-centric servitization strategy (www.rollsroyce.com/service/civil). Many other western companies, especially those in industry sectors with high installed product bases (e.g., locomotives, elevators, machine tools, business machines, printing machinery, construction equipment and agricultural machinery), are also following such strategies and inevitably face similar challenges. These and other companies seek to understand how they might deliver integrated products and services with greater efficiency and effectiveness.

\subsection{Definitions within servitization}

Fundamentally the terms service and product are intrinsically linked to discussions about servitization. The term 'product' is generally well understood by manufacturers. Goedkoop (1999) defines a product as a tangible commodity manufactured to be sold, and quite simplistically is capable of 'falling on your toe' . Academics typically refer to this as a 'good' (Judd, 1964). Invariably, in the world of manufacture, such a product is represented by a material artefact (e.g. Car, boat, plane). We use Goedkoop's definition throughout the paper. The term 'service' is more contentious, often used loosely in the literature, and typically defined based on what it is not (i.e. a product) rather than what it is (c.f. Schmenner 1995). Here, 'service' usually refers to an offering (e.g.: maintenance, repair, insurance). However, 'service' is also used to refer to a level of performance (e.g., that was good service). To avoid confusion, and for the purpose of this paper, we will consider that the service refers to an "economic activity that does not result in ownership of a tangible asset" (Oxford English Dictionary). We will avoid using the term service as a measure of performance.

The first use of the term servitization in a context of manufacturing operations was by Vandemerwe and Rada in a 1988 European Management Journal article titled 'Adding Value by Adding Services'. They defined servitization as "the increased offering of fuller market packages or 'bundles' of customer focussed combinations of goods, services, support, self-service and knowledge in order to add value to core product offerings" (p.314). Their paper discusses the evolution of the servitization concept, describing how companies initially considered themselves to be in 'goods' or 'services' (e.g., automobile or insurance), and then moved to offering goods combined with closely related services (e.g., products offered with maintenance, support, finance, etc.). It is this form of servitization considered here.

\subsection{Previous research associated with Servitization}

There are five clusters or communities of researchers currently engaged with servitization of manufacture. These are summarised below. Here, our focus has been on literature dealing with 
'bundling' in the context of combining products and services, as opposed to the 'bundling' of product features as highlighted in the market segmentation literature (e.g. Haley, 1968).

\section{Servitization}

Since 1988 the most definitive papers have come from the USA followed by contributions from the UK and Western Europe, and all have their origins in the managerial and business practitioner literature. For example, Chase and Garvin (1989) discuss operating factories whose activities reflect the new role of service in manufacturing; Quinn (1990) argues that value-add is now more likely to come from the addition of services; while Wise and Baumgartner (1999) suggest that manufacturers need to "go downstream towards the customer" (p.133). This motivation is based on revenue generation, especially for companies with large installed product bases (Windahl et al, 2004; Ward \& Graves, 2005; Slack, 2005). Methods for the delivery of services are proposed together with some of the potential barriers to success (Oliva \& Kallenberg, 2003; Sawhney, 2004; Gebauer, 2004; Brax, 2005). Examples of successful implementation of a 'servitization' strategy include Cable \& Wireless ('value generating integrators': C \& W, 1999) and Alstom Transport ('train availability': Owen, 1997). Here, customers are buying a guaranteed solution for trouble free operation (Davies, 2006), where relationships within the delivery network play a key role (Windahl \& Lakemond, 2006)

\section{Product Service System (PSS)}

A PSS is an integrated product and service offering that delivers value-in-use (Baines et al., 2007). This concept originated in Northern Europe in the late 1990s (Goedkoop, 1999) and to date, most contributors have been academics from the environmental and social sciences (Mont, 2000; Meijkamp, 2000; Manzini \& Verzolli, 2003), publishing in journals focussing on sustainability and cleaner production. A diverse range of PSS examples can be found in the literature with some demonstrating economic success but most tending to emphasise significant environmental and social gains (Oman, 2003). PSS solutions are seen as having the potential for decoupling environmental pressure from economic growth through focussing on asset use rather than on asset ownership (Tukker, 2004). There are, however, some key barriers to the adoption of PSS. For instance, consumers may not be enthusiastic about ownerless consumption (Mont, 2001). Similarly, while some methods and practices are proposed for designing and operating a PSS (Luiten, 2001; Maxwell, 2003), these tend to lack the pedigree that is formed through careful evaluation in practice. The lack of regulatory drivers in developed countries and the cultural shift required for consumers to place value on having a need met as opposed to owning a product are perceived as the key barriers to the adoption of a PSS (Mont, 2001;Mont,2003; Wong, 2004).

\section{Services Marketing}

In the first issue of the Journal of Marketing, a review of research being undertaken at that time indicated that much of the work focussed upon the exchange and distribution of commodities (Taylor, 1936). Over the intervening 20 years the emphasis of marketing moved from economic exchange to marketing management (Vargo and Lusch, 2004) with a focus on satisfying the customer coming to the fore (e.g. Drucker, 1954). In the following decade the marketing mix (e.g. Kotler, 1967) - or the 4 P's - of product, price, place and promotion added further granularity to the way in which a firm could adjust it's offering independently of market factors to satisfy their customers. In the late 1970s there was acknowledgement that the marketing of services was different to products (Shostack, 1977). Furthermore, products and services are often inseparable and the sale of a product would lead to a relationship where services could be sold over an extended period of time (Levitt, 1983) moving marketing from transactional to relational exchange and an acknowledgement that goods and services needed to be treated differently. 
The work of Shostack (1977) and Levitt (1983) acted as the precursors of two new streams of marketing services marketing and relationship marketing. Services marketing scholars argued that the marketing of goods and services is different as services are intangible, heterogeneous, inseparable and perishable (Fisk et al., 1993). Conversely, the relationship marketing literature is founded on the premise that competition is between firms and that exchange between actors increasingly has a temporal, relational dimension as opposed to being solely about discrete transactions (Morgan and Hunt, 1994). In the early $21^{\text {st }}$ century these two emergent fields of marketing converged to inform the "Service-Dominant Logic" (SDL). In the SDL the customer acts as co-creator of value with the firm - through an ongoing relationship - and goods acting as vehicles for the delivery of services (Vargo and Lusch, 2004.

\section{Service Operations}

In the paper 'The Industrialisation of Services' (1976) Theodore Levitt points out that, even at that time, the service sector of industrialised nations had been in the ascent for almost three quarters of a century. Davis and Heineken (2007) discuss the emergence of service operations management and, go on to argue, that applying manufacturing operations concepts to the management of service operations is limiting and that there is a need for a trans disciplinary approach appropriately suited to the characteristics of services industries (Sasser, 1976). The 'Service Factory' concept (Chase \& Garvin, 1989) is seen as a key contribution in reversing the trend in operations management literature, which focussed on manufacturing based concepts in a services environment (Voss, 1992). The classification, positioning and deliver strategy for services has been addressed by a number of authors, for example: Silvestro et al, (1992) propose service positioning along a process diagonal; Collier \& Meyer (1998) use four service quadrants based on labour intensity and customer contact; and Kellog \& Winter (1995) introduce a service process / service package (defined by the degree of customisation) positioning matrix.

\section{Services Science}

Originating in the IT sector, services science is a relatively new interdisciplinary concept for services. It focuses, not merely on one aspect of service, but rather on service as a system of interacting parts that include people, technology, and business (Chesbrough \& Spohrer, 2006). It is a melding of technology with an understanding of business processes and organisation. As such, service science draws on ideas from a number of existing disciplines including computer science, engineering cognitive science, economics, organizational behavior, human resources management, marketing, and operations research. It aims to integrate them into a coherent science of service.

\subsection{Existing classifications of production and service operations}

In setting out to propose an operations strategy for product-centric servitization, we recognise that various models, taxonomies, typologies already exist. Production centred frameworks are typified by those of Hayes and Wheelwright (1984) and Hill (2000). Hill, for example, illustrates how a jobbing production structure should differ from project, batch, line or continuous processing. He suggests differences in products and markets, order winners and qualifiers, manufacturing capabilities, investment, cost and infrastructure. To a manufacturer this provides a relatively detailed description of the required configuration for product delivery, but offers little guidance for those concerned with servitization.

The service operations literature suggests a number of frameworks for classifying services (see Cook et al 1999 for a review). For example Collier and Myer (1998) proposed a Service Positioning Matrix (SPM) to establish a delivery system based on the nature of the required customer service. This is roughly analogous to Hayes and Wheelwright's (1984) product-process matrix (Silvestro et al, 1992). Silvestro et 
al (1992) provide a similar review of classification matrices, including those of Maister and Lovelock (1982) and Haynes (1990), where services are positioned into four categories in terms of the level of customisation and customer contact. They suggest that a 'service volume' measure unifies the classifications into three categories: the 'professional service', 'service shop' and 'mass services'. The forth category of 'service factory' (Chase \& Garvin, 1989) becomes simply "an integrated view of product and service" as opposed to a service classification (Silvestro et al, 1992, p.74).

The body of literature that deals with both product and service is typified by the work on PSS. In the PSS literature authors such as Mont (2000), Tukker (2004) and Wong (2004) propose classification frameworks. In these, pure product manufacture is positioned at one end of a continuum that moves through product service systems, to the opposite extreme of pure service provision. Shostack (1982) uses a similar framework with pure product and pure service at the extremes, but does not characterise the 'middle' ground combinations of products and service as a PSS, rather, she simply refers to varying levels of product and service mix. The framework proposed by Tukker (see Figure 1) is widely acknowledged as illustrating differing forms of a product-service system, which include product oriented services, use oriented services, and result oriented services. Tukker's framework is, however, typical of many in the PSS literature in that it tends to focus on the features and examples of the offering (it describes a car leasing model) rather than focusing on the intrinsic values (cost, quality, time). Hence, while useful in terms of organisational positioning, it is of limited value to an organisation seeking to configure their wider production and support service operations.

Insert Figure 1 about here

This approach is unsatisfactory.

\section{Research Design}

\subsection{Research question and programme}

A servitization strategy is now widely advocated as a means by which western manufactures can face-up to the challenges of competitions in lower cost economies (Vandermerwe \& Rada, 1988; Wise \& Baumgartner, 1999; Tukker, 2004). Such offerings can be delivered by decoupling product manufacture from service delivery, but this is unlikely to be a sufficient response in an ever increasing competitive environment as it makes insufficient capital of sharing of resources, people, information, etc. Hence, it results in a myriad of issues and lost opportunities for the traditional product manufacturer. A more integrated operations strategy is desired. The extant literature covering servitization, PSS, service operations, service marketing and services science offers a selection of frameworks, models and classifications. These provide some guidance on how to configure an operations strategy for servitized manufacture, but are in themselves insufficient to provide a complete and detailed picture of the integrated delivery of products and services, and their effect of service provision on internal manufacturing operations. Therefore, the research question arises as to how to provide an efficient and effective service delivery system that is integrated into original equipment manufacture? As previous work in this area is largely conceptual, and by contrast operations strategy is relatively complex topic in investigate empirically, our approach has been to carryout an in-depth case study of a single company. This has been a largely inductive study, being loosely guided by a theoretical framework (section 4). The results of this study have then been synthesised with the existing literature, and from this our framework for productcentric servitization has been formed. This case study design is summarised in the following sections. 


\subsection{Data collection protocol}

Case-based research is appropriate for exploratory and theory building research, suitable for dealing with 'how' type questions (Voss et al, 2002; Yin, 2003). The unit of analysis for the research is an organisation that designs, builds and delivers integrated product-service offerings. The case design used a purposive sampling strategy. A semi-structured data collection protocol was developed through a two-day workshop attended by a multidisciplinary team of management, engineering and manufacturing researchers. The use of researchers from different disciplines allowed different avenues of inquiry to be pursued in the data collection (Meredith, 1998). The resultant protocol focussed on determining how and why the case company had begun to deliver servitized offerings and the challenges this was posing for their manufacturing and wider operations. A series of guiding interview questions were identified. These were organised around the 'theoretical framework' that is presented in section 4. A selection or questions were formed to reflect this framework, typically they included:

$>$ How does your company do business, and what do your customers value?

$>$ How is this value measured, and what performance is key to success?

$>$ How have you organised your operations to deliver this performance?

$>$ Has such a strategy caused issues to arise, and what are they?

\subsection{Case selection}

Choice of case company was critical to this study, as we sought to investigate a manufacturer who has a track-record of achieving business success through providing a portfolio of product related services. Therefore, our case study organisation is a UK based OEM that designs and manufactures high value capital equipment for the power, defence and aerospace markets. For reasons of confidentiality and in order to give us greater freedom to discuss our results and findings, we refer to the company as 'ServitCo'. The company, which operates globally and today generates over $50 \%$ of revenues from the provision of services that are closely coupled to its products. Whilst ServitCo continues on its servitization journey, it is sufficiently advanced to provide a basis for exploring the characteristics of an operations strategy in this evolving context. This transformation is not trivial and ServitCo has faced many challenges. As the Service Operations Director revealed, "I feel that we have been, if you like, running a service business on production principles". However, the company has made significant progress and is at a relatively advanced stage of servitization for a traditional manufacture. This was confirmed by the HR Director who acknowledged that, " $\ldots$ at the interfaces between the company and the customer I think we're [now] seeing far more evidence of responsive agile service centred behaviour". The servitization journey continues as ServitCo sees ever increasing opportunities in the market place.

\subsection{Results and data analysis}

Data was collected between June and November in 2007. Interviews were conducted with key personnel from across the organisation (c.f. Design Engineering, Global Component Repair, Service Innovation/ Marketing, Projects, After Market Services, Global Component Repair, Manufacturing Operations, Customer Services and Supply chain). Each of the 15 interviews lasted between 2 and 3 hours and was recorded and subsequently transcribed. Theoretical triangulation (Jick, 1979; Yin, 2003) was achieved through the collection of supplementary data such as organisation charts, process maps and operating protocols in addition to viewing the operations within the business units of the key informants. Each interview was carried out by $2 / 3$ researchers from cross disciplines. For instance, the manufacturing operations key personnel were interviewed by representative from the three above mentioned disciplines. On the other hand, the supply chain managers were interviewed by the management and manufacturing researchers. The interviews were then coded and analysed by the same team of researchers using 
guidelines proposed by Miles and Huberman (1994). These results were then synthesised with the literature to construct the framework that is presented in the remainder of this paper.

\section{Structuring the framework for product-centric servitization}

This section summarises the principal constructs of the theoretical framework, which was then used to guide the case study investigation.

\subsection{Scope of characteristics within the framework}

Existing frameworks, such as those provided by Hill (2000) and Hayes and Wheelwright (1984), are carefully targeted at particular aspects of production operations and identifying their associated characteristics. For example, Hill's framework is only relevant when positioning differing production demands (e.g.: low, medium \& high volume) against types of production system (e.g.: jobbing, batch, line). Hence the framework being developed here is targeted at an operations strategy for the integrated delivery of products and services. For example, in the aerospace sector we would see Goodridge as typifying production operations, Virgin Airlines as typifying service operations, and Rolls-Royce', 'TotalCare' as typifying product-centric servitized operations. We are mindful that each of these companies is a larger organisation and, therefore, such characterisation may not be entirely accurate for the totality of their operations.

Within the scope of the servitization framework developed here, some form of comparison is required between general production operations, service operations, and our hybrid product-centric servitized operations. However, difficulties can arise because each of these categories can themselves be subdivided. For example, under the production category we can have batch, mass, etc. (Hayes \& Wheelwright, 1984; Hill, 2000). Likewise, under services we can have professional, service shop, mass, etc (Silvestro et al, 1992; Collier \& Myer, 1998). We have therefore been mindful to compare like-with-like (i.e., 'mass production can be likened to 'mass services'), whilst being comprehensive (i.e.: attempting to include most characteristics of production and service operations), and yet avoid becoming overwhelmed in detail.

\subsection{Categorisation of value characteristics within the framework}

From Ford (1920) through to the work on Lean systems (Womack et al, 1990), the starting point of operations strategy formulation is always to understand customer value requirements. Likewise manufacturing strategy researchers, from Schroeder and Lahr (1990), Mills et al. (1995) to Hill (2000), all propose design processes that start with customer value dimensions using measures such as cost, quality and timeliness. Therefore, it seems appropriate that any classification of servitization should take on a similar approach, and that value should be a key category in our framework.

\subsection{Categorisation of operations characteristics within the framework}

The question then arises as to the categories of operations characteristics. An indication of the appropriate categories is provided by reviewing existing classification systems for manufacture (e.g.: Hayes \& Wheelwright, 1984; Hill, 2000). There are a number of these, with little to suggest that any one classification is more rigorous and complete. It is on this basis that we have constructed Table 1. This brings together the views of existing authors and translates these into 'Principal Categories'. This table 
reflects the earlier findings of Mills (1996), that many writers in the field have developed their own set of categories. However, as Anderson (1989) points out, agreement amongst these is generally high. We have therefore used these categories as the basis for understanding operations characteristics within our proposed framework.

Notably absent from the manufacturing-oriented frameworks is a consideration of customer relations, whereas this is a highly important element present in most service design frameworks (Haywood-Farmer, 1988; Silvestro, et al., 1992). This omission is indicative of the internally centred view of manufacturing endemic to most manufacturing organisations, where manufacturing operations are typically far removed or at least buffered from customer interactions. The design of an integrated servitized product system, however, must consider the customer interface. Accordingly, we have added 'customer relations' as a principal design category.

Insert Table 1 about here

\section{Populating the framework}

As outlined above, the theoretical framework has three principal categories covering scope, value, and operations characteristics. In this section we populate this structure and develop the full framework through an analysis and synthesis of the literature with data collected from the case study organisation.

\subsection{Scope of the framework}

As mentioned above, the framework is intended to capture the general characteristics of product-centric servitized operations strategy. These are illustrated along side larger and somewhat conventional manufacturers (representing production operations); larger and somewhat conventional services (representing service operations); and bespoke products sold with a bundle of services (representing product-centric servitized operations). For each our unit of analysis is the Strategic Business Unit (SBU). All these characteristics are grouped under 'scope' in Table 2.

\section{Insert table 2 about here}

\subsection{Characteristics of value}

Understanding the differing dimensions of value is key to the framework. Some broad appreciation of how value propositions differ is gained by reflecting on the business model associated with the three operations strategies shown in table 2. Thompson (1967) suggests that value can be created through transformation (e.g.: raw material), problem solving (e.g.: consulting) and mediation (e.g.; banking). This complements a view that value creation can be both transactional and relational. Building on some of Thompson's work Stabell \& Fjeldstad (1998).explore the ideas of value chain, value shop and value network. Production operations tend to support a more transactional approach, whereas service operations tend to be more associated with customer relationship development. This is further supported by reflecting on what a typical customer of each business model will value. Customers of a pure producer will tend to value the ownership of the artefact. Customers of a pure service provider will, on the other hand, tend to value the functional result. For the product-centric business, the focus is likely to be a blend of transactional activities (to deal with the initial sale of the product) and customer relationship activities to deal with the initial product design, use, and return at end of life. This is evident in our study with ServitCo where delivering customer value was of key concern and exemplified by a Service Operations Manager when commenting that, "we as an organisation need to have a much better understanding of the value of service to a customer, rather than what we think value of a service is". 
A more in-depth understanding of the value proposition is gained through the work of Hill (2000) whose framework emphasizes the importance of order winning criteria. Here production operations are associated with a business model where orders are won and lost on measures such as product specification, quality conformance, and delivery. Such measures translate into a similar set of performance metrics internal to the production systems. In service operations, where success tends to be more biased toward relationships, success in winning orders is associated with intangible and more subjectively assessed attributes. Internally, metrics associated with speed of response are often key. For a servitized product offering, the measures become a subtle blend, changing from transactional as a product is initially sold, to relationship as the product is supported in use. All these are grouped under 'characteristics of value' in Table 2.

\subsection{Characteristics of operations}

Production operations tend to be configured on conventional manufacturing principles focused on the physical transformation of materials into tangible goods. Whereas within service operations the focus is on delivering experiential transformation for the customer through facilitation and mediation. The operations strategy for product-centric servitization will again require a subtle blend of these two extremes. This section explores this blending across the structure and infrastructure of an organisation. All these are grouped under 'characteristics of operations' in Table 2.

\subsubsection{Structural characteristics}

\section{Process and Technology}

This category deals with the physical resources and technologies that are used within operations. For conventional production operations, the tendency is towards the automation of processes in order to reduce worker intervention and achieve high levels of product conformance. This is a common theme within much of the literature associated with manufacturing system design (e.g. Swamidass, 2000). Within service operations, processes embody the use of intensive, mediating and long-linked technologies. In particular, IT systems enable higher levels of customer optimisation with minimal customer influence Kellog and Winter (1995). For product-centric servitized operations, authors such as Quinn (1990) suggest that processes and technologies should be built around service delivery. An example of this in the case study organisation was the development of special fixtures that enabled the rapid replacement of critical product components in the field. Likewise, good integrative information systems and management processes (Brax, 2005), along with tools to allow enhancement of company knowledge and best practice (Byron, 2006), are all essential to competitive success. ServitCo recognise the need to achieve this across the business and resolve issues. As exemplified by the statement from the Engineering Manager that, ".... we've got lots of data but it's not in the same format, some is paper, some is electronic, some is mainframe, some in pc's, some is in different businesses".

\section{Capacity}

Classically the operations management literature suggests that production capacity should be matched to demand in order to ensure utilisation of expensive resources (Hayes \& Wheelwright, 1984). Conversely, within service operations, lower capacity utilisation is accepted in order to be able to meet peak demand in high contact systems (Chase, 1979), and to 'chase demand' in low contact ('service factory') situations (Kellog, 1992). The matching of supply and demand in service industries is, however, not easy (Sasser, 1976). Product-centric servitized operations, as observed in our case study company, are characterised 
by multiple customer touch-points. Each of these can generate varying capacity demand signals and necessitate differing forms of response from the host organisation. For example, maintenance and repair activities need to be configured to respond to unscheduled demand, such as unforeseen component failures, and so lower levels of capacity utilisation are necessary. This is highlighted in ServitCo by one Service Delivery Operations Manager noting that "....you need that capacity, .... creating buffers to deal with variability..... traditionally you can use inventory or more capacity". This contrasts with their product build and test organisation, which experiences more stable demand cycles and so a greater level of capacity utilisation is achievable.

\section{Facilities}

Within the operations strategy literature, the facilities decision typically includes the choice of production sites, their location and specialisation (c.f. Hayes and Wheelwright, 1984). Clues as to the popular characteristics of facilities are provided by a wide range of authors including Ford (1922), Skinner (1985) and Womack (1990). In all these cases, an underlying reason for the existence of factories is to exploit economies of scale by bringing together and centralising manufacturing activities that exploit resource availability. Conversely, facilities for service operations tend to focus more on accommodating customer's expectations, physical and psychological needs, and enhancing the customer experience (Chase, 1978). In the case of product-centric servitized operations, evidence from the projects organisation in ServitCo suggests that the "organisation needs to position [location] itself to be responsive to customer requirements" [Customer Services Director]. They achieve this through a combination of centralised manufacture, mainly focusing on product final assembly and test, along with multiple field facilities for maintenance and repair. These field facilities are located close to the customer's operations, as many of the service activities may need to be carried out on the customer's site.

\section{Supply Chain Positioning}

Traditionally, production based organisations have tended to be vertically integrated to maximise quality conformance, minimise cost, and ensure control over material supplies. Evidence of this is most clear in the practices of Ford (1922) with his production of the Model T earlier in the $20^{\text {th }}$ century. While improvements in supplier capabilities, a focus on core competences (Prahalad \& Hamel, 1993), and greater use of outsourcing (Baines, 2005), have changed the apparent structure of supply chains the underlying concerns with cost and quality have largely endured. Service operations tend to focus more on providing a platform of capabilities that deliver a compete solution to the customer. Our case study suggests that product-centric servitized operations use a combination of practices. Within ServitCo, the manufacture of products still reflected a desire to control costs and quality, and so remained relatively vertically integrated. However, for effective service delivery they realise that. "we have got to change the way that we interrelate and organise and drive ourselves" [Supply Chain Director]. As a result partner organisations have been engaged to assist in the delivery of services. Here, Davies (2004) notes that successful providers of integrated product-service solutions are becoming less dependent on broad based in-house capabilities.

\section{Planning and Control}

Production operations will generally use automated master production scheduling, planning and control systems which can be large, complex and expensive (Ranky, 1983). For effectiveness, these systems need to be linked to markets and processes (Hill, 2000). This is in contrast to service operations, which 
rely on individuals and project planning techniques to respond to customer requirements. Chase (1978) notes that forecasting can be short-time or long-time output oriented.. In the case of product-centric servitized operations planning and control systems encompass hardware manufacture and maintenance, service processing and data storage, and decision making Rasgado (2004). At ServitCo, senior management in their service organisation recognise that "being more joined up between your delivery arm and your commercial arm and the customer service groups becomes much more imperative" when the emphasis is on product availability and delivery of functionality and provide capability to the customer.

\subsubsection{Infra-structural characteristics}

\section{Human Resources}

Some of the key developments in production operations during the $20^{\text {th }}$ century have been in the way people have been integrated into manufacturing systems. Ford (1922) revolutionised automotive manufacture by de-skilling the tasks of the assembly worker. This was achieved through the sub-division of labour and strictly defined and controlled production routines. This approach has prevailed in large right up to the present day. Although Toyota is widely recognised as the leading manufacturer of automobiles world-wide, the production activities remain highly procedural. This contrasts with service operations, where value tends to be delivered through skilled workers who have good customer interface and communication capabilities. In particular, where there is high customer contact the workforce is a major part of the service product and so must be able to interact with the customer (Chase, 1979). Brax (2005, p151) argues that "...credibility of expertise is fundamental ...", and similarly, Vandermerwe and Rada (1989, p.44) note that "... people must identify with individual customers". Managers responsible for service provision at ServitCo highlight that "delivering services is not easy - it needs people training and there is a lot of complexity especially when you're talking about services that interface with complex difficult products" and it needs "people who are customer focussed, running processes that work smoothly" Such resource can not necessarily be found internally and their approach was summarised in the operations manager's statement that, "we can't do it all ourselves, so we'll be buying in the expertise to enable us take more service [business] from our customers". This suggests that in a product-centric servitized operation, workers are required who have both high levels of product knowledge and an ability to manage and develop ongoing customer relationships.

\section{Quality Control}

As highlighted in The Machine That Changed the World (Womak, 1990) the most efficient production operations have introduced Lean Manufacturing techniques where quality control is focussed on achieving product conformance and the minimisation of waste in materials and resource usage. This is achieved through a variety of techniques, such as Statistical Process Control, Statistical Quality Control, Quality Circles, and Poke Yoke (Liker, 2004). The quality of delivery in service operations tends to be measured through individuals developing appropriate criteria and subjectively judging performance against these or surveying the customer. These systems need to cope with customers having a set of intangible requirements which may exist at a range of levels of consciousness, these form part of the customer perception of an acceptable service (Morris, 1987). At ServitCo it is apparent that the physical product quality tends to be controlled using traditional production techniques. However, at the management level in product design there is an understanding that " [product] reliability, maintainability and reparability are important" [Engineering Manager] and that service quality is a measure of a products availability to deliver functional performance for the customer. A product that is reliable, easy to maintain and quickly repaired 
is essential to the delivery of the level of service quality expected by customers. The services director acknowledged that a major challenge at ServitCo was.. "to get in control of [service] consistency".

\section{Product / service range}

In production operations the range of product may vary greatly, from large in the case of project type build, to very narrow in mass production systems (Hill, 2000). Whilst systems can be configured to cope with product variety, production efficiencies are best preserved by producing higher volumes of a limited product range. This is also largely the case in service operations. An equivalent classification of delivery systems, to that for production, is available (e.g. Silvestro et al, 1992) but organisations tend to favour less variety. There is limited guidance in the literature as to what to expect in a product-centric servitized operations. In ServitCo, the common perception in customer facing units is that "normally a new service is actually adding onto an existing design" [Engineering Manager]. This suggests that in this type of organisation we would tend to find a limited range of physical products that are closely combined with varying 'bundles' of supporting services. This "pick and mix" / Chinese menu approach to services was, however, of some concern to executives involved in service innovation since customers who removed service elements from the total package expected some reduction in service charges, yet, potentially reduced the scalability of the offering and hence added to ServitCo's overall cost of service delivery.

\section{New product / service Introduction}

Methodologies for new product introduction (NPI) inside traditional manufacturers have received attention from many authors (e.g. Womak, 1990; Haque, 2003; Oppenheim, 2004). Whether set based, point based or concurrent engineering techniques are used, new products are thoroughly designed and tested before their release into the market place. These design activities tend to be decentralised into business units (Wong, 2004). In most service operations, new services will be highly tailored to customer expectations and often co-developed with the customer. Here, the testing, refinement and improvement of new services tends to be done 'in the field' with the customer. As Levitt (1981) argues, services can seldom be tried out, inspected or tested in advance of their introduction to the market. This requires the development of customer trust and an understanding of customer habits and behaviour (Lovelock, 1979). Our study with ServitCo indicates that NPI in product-centric servitized operations, a similar process to that in more conventional production is followed. This process has, however, an increased emphasis on those design aspects impacting on maintenance and repair activities' which are integral to the overall product-service offering. The Service Operations Director articulated this with a view that "the best thing you can do is design it [the product] knowing you're going to have this service out there". Miller (2002) highlights the importance of the NPI process being client centric with solutions tailored to desirable client outcomes, this was an approach, which ServitCo were adopting ..... "making us think a lot more about our products, their predictability an how we can design them so that they're more customer friendly and meet the customers expectations" [Projects Manager].

\section{Performance measurement}

In delivering value to customers the performance of traditional product operations is general measured against criteria such as 'to cost', 'to specification' and 'delivery on time'. However, Gebauer (2005) argues that service operations tend to use different customer and employee satisfaction and business success criteria. Coyne (1989) points out that delivery performance in the customers view consists of many different interactions (service encounters) and each must be measured separately, and each depends on whether it is environmental, transactional or assistance-based. Furthermore, Morris's (1987) suggests 
that the perception of acceptable service varies from one customer to another. In product-centric servitized operations, (Lewis, 2004) suggests that effective performance is measured against the following: customer expectations of service (and hence product availability), co-location and speed of response. ServitCo use a 'disruption index' KPI as measure of product availability and a 'resolved customer incidents' KPI as a measure of speed of response since here the Operations Director commented that, "problem resolution ... it's probably a measure of agility and responsiveness". The company also locates service operations units close to its customer's operations centres.

\section{Customer Relations}

The transactional nature of manufacturing operations generally leads to a relatively limited interaction with end customers and, instead, energies tend to be invested internally to improve operational efficiency. This contrasts with service operations where there is a stronger need to invest in developing and maintaining relationships with customers. Here, customer relationships do not begin and end with a single transaction, rather investment in Customer Relationship Management enables the building of stable, iterative and long tem relationships (Verstrepen, 1988). Product-centric servitized operations also have strong interaction with customers. ServitCo's HR Director was of the opinion that "at the interfaces between the company and the customer ... we're seeing far more evidence of responsive agile service centred behaviour ". This is consistent with Davies (2006), who suggests that such customer facing units are necessary in these organisations in order to deliver the requirements of customers in different industry segments and groups and across a range of customers and projects.

\section{Supplier relations}

Effective management of the supply chain is critical for efficient and effective production operations. Here, there is some debate within the literature as to the relative benefits of partnership (Lamming, 1993) and power (Cox, 2001). A 'partnership' goal is often adopted in service operations (Windahl, 2004); however, this can generate an expectation that suppliers will provide the same responsiveness and commitment to the service provider as that received by service customers. Our study with Servitco highlighted their desire to resolve the problem of "how do we align our supply chain to what the customer really wants" [Projects Manager] in order to deliver a product-service offering. To be effective it is important to align supplier relations in both internal and external supply chains. The Purchasing Director commented that, "...there's intent to try and get to partner with our suppliers on a win/win basis rather than on a deliver us the parts, ...we'll manage everything from there". However, internal 'functional silo' behaviours, along with a tendency to adopt forceful corporate leverage with external suppliers, can adversely impact success.

\section{Concluding remarks}

Servitization is now widely recognised as the innovation of a manufacturer's capabilities and processes to move from selling products, to selling integrated products-service offerings that deliver value in use. Such a strategy is advocated as a means by which western manufactures can face-up to the challenges of competitions from lower cost economies. However, to deliver this offering to the marketplace, we typically find that product manufacture and service delivery are largely decoupled. This approach is unsatisfactory as it results in a myriad of issues and challenges emerging for the traditional product manufacturer. A more integrated operations strategy is desired. 
This paper has set out a series of indicative characteristics for servitized manufacture. In summary, with product-centric servitized offering the business focus is likely to be a blend of transactional activities supported by a customer management function that is configured to deliver the core product and the services related to supporting the use of the product. Structurally, this delivery system will tend to be configured around product assembly, with test and repair capabilities located near to customers. There will be a focus on response time with heavy reliance on their associated supply chains. Internal structures are likely to be cross functional. Planning and control will emphasise the optimisation of product availability for the servitized offering. Employees will have high levels of product knowledge, blended with customer management and relationship development skills. Finally, product ranges are likely to be limited and consist of similar products combined with differing 'bundles' of supporting services.

The contribution of this paper is two fold. First it proposes a set of theoretical constructs for the effective and efficient delivery of products and their associated services. This contribution is reflected in our framework presented in Table 2. This framework bridges the gap between models and classifications that focus on either pure product or pure service operations, by exploring the configuration of resources to deliver product-centric servitization. Second, it provides a basis from which to construct a set of guidelines to assist practitioners in moving their organisations up the value chain with a servitized offering.

The work is based on a review of the literature supported by data collected from an exploratory case study. Whilst we believe it provides an essential platform, we recognise that our work may be limited by the use of a single, although in-depth, case study. Taking evidence from a single case does not, necessarily, imply that the findings are true of a wider set of organisations. In our case, ServitCo may not yet have completed it's servitization journey such that it represents an optimum solution. There is, however, little to suggest that their progress is insufficient to inform the basis of the theoretical framework that we propose in the is paper. The challenge now, therefore, is to use this framework as a basis for further empirical work. To do this we will target and study in-depth a selection of international organisations who are succeeding in the delivery of product-centric servitized offerings. The data captured will then be analysed and synthesised to allow us to propose a generic service delivery system strategy, or indeed strategies. We look forward to reporting on this work in future papers.

\section{Acknowledgements}

We would like to acknowledge the support of EPSRC via the Cranfield Innovative Manufacturing Research Centre programme for providing the funds for this research. We would also like to thank our anonymous reviewers for their constructive and insightful comments. 


\section{$\underline{\text { References }}$}

Alonso-Rasgado T. et al, (2004) "The design of functional (total care) products", Journal of Engineering Design, Vol.15, No. 6, pp. $515-540$

Anderson J. et al., (1989), "Operations Strategy: A literature review", Journal of Operations Management, Vol. 8, No. 9, pp. 133-157

Anderson J. \& Narus J., (1995), "Capturing the value of supplementary services", Harvard Business Review, Jan-Feb, pp. 75 - 83

Auramo J. \& Ala-Risku T., (2005), "Challenges for going downstream", International Journal of Logistics: Research and Applications, Vol. 8, No. 4, pp. 333-3

Baines T., et al., (2005), "Strategic positioning - An integrated decision process for manufacturers", International Journal of Operations and Production Management. Vol. 25, No. 2, pp. $180-201$

Baroth E. et al., (2001), "IVHM (Integrated Vehicle Health Management techniques for future space vehicles", $37^{\text {th }}$ Joint Propulsion Conference Exhibit.

Bird G. et al., (2005), "Use of Integrated Vehicle Health Management in the field of commercial aviation", NASA ISHEM Forum Scandura P.A.

Brax S., (2005), "A manufacturer becoming service provider - challenges and a paradox", Manufacturing Service Quality, Vol. 15, No. 2, pp. $142-156$.

Byeron A. et al, (2006), "The right service strategies for product companies", McKinsey Quarterly, Vol. 1, pp. 40-51

C\&W, 1999, "Global outsourcing and thenetworked economy: Telecom's opportunity to deliver real competitive advantage", London: Cable and Wireless.

Chase \& Garvin, (1989), "The Service Factory”, Harvard Business Review, Vol. 67, No.4, pp. 61-69

Chase R., (1978), "Where does the customer fit in a service operation", Harvard Business Review, Vol.56, No. 6. pp $137-142$.

Chesborough, H. \& Spohrer, J., (2006), "A research manifesto for services science", Communications of the $A C M$, Vol. 49 , No. 7, p. 35

Cohen M. et al., (2006), “ Winning in the Aftermarket”, Harvard Business Review, May, pp.

Cohen M. (2007), "Power by the Hour: can paying only for performance redefine how products are sold?", www.knowledge.wharton.upenn.edu

Cook D et al., (1999), "Service Topologies: A state of the art review", Production \& Operations Management, Vol. 8, No. 3, pp. 318-338

Collier D. \& Meyer S.. (1998), "A service positioning matrix", International Journal of Operations and Production Management, Vol. 18, No. 12, pp. $1223-1244$.

Correa H. et a., (2007), "An operations management view of the service and goods mix", International Journal of Operations and production Management, Vol. 27, No. 5, pp. 444-463 
Cox A., et al., (2001), "Supply chains and power regimes: Toward an analytic framework for managing extended networks of buyer and supplier relationships", Journal of Supply Chain Management; Vol. 37, No. 2, p. 28

Coyne K., (1989) "Beyond service fads Meaningful strategies for the real world", Sloan Management Review, Vol. 30, No. 4, pp. 69-76

Davies A. et al, (2004), "Moving base into high-value integrated solutions: a value stream approach", Industrial and Corporate Change, Vol.13, No.5, pp. 727-756

Davies et al., (2006), "Charting a path towards integrated solutions", MIT Sloan Management Review, Vol. 43 , No. 7 , pp. $39-48$.

Davies A. et al, (2006), "Organizing for solutions: Systems sellers vs. systems integration”, Industrial Marketing Management, Vol. 36, p183-193

Drucker, P.F. (1954) "The Practice of Management", New York: Harper and Row

Fisk, R.P., Brown, S.W. and Bitner, M.J. (1993), "Tracking the Evolution of the Services Marketing Literature." Journal of Retailing, Vol. 69, No. 1, pp. 61-103

Ford H., (1922), "My Life and Work", Kessinger Publishing.

Fox J.\& Glass B., (2000), "Impact of Integrated Vehicle Health Management (IVHM) Technologies on Ground Operations for Reusable Launch Vehicles (RLVs) and spacecrafts", Aerospace Conference Proceedings

Gebauer H. et al., (2004), "Overcoming the Service Paradox in Manufacturing Companies", European Management Journal, Vol. 23, No.1., pp. $14-26$.

Goedkoop M. et al, (1999), "Product Service-Systems, Ecological and Economic Basics", Report for Dutch Ministries of Environment (VROM) and Economic Affairs (EZ)

Haley R., (1968), "Benefit Segmentation: A Decision - Oriented Research Tool”, Journal of Marketing, Vol.32, pp 30-35

Haque B., (2003) "Lean engineering in the aerospace industry", Proceedings of the Institution of Mechanical Engineers, Journal of Engineering Manufacture, Part B, Vol. 217,

Hayes R. \& Wheelwright S., (1984), "Restoring our competitive advantage through manufacturing", Wiley, New York

Haynes R., (1990), "Service Typologies: A transaction modelling approach", International Journal of Service Industry Management, Vol. 1, No. 1,

Haywood-Farmer, J. (1988), "A Conceptual Model of Service Quality", International Journal of Operations and Production Management, , 8, 6, 19-29.

Heineke J, \& Davis M., (2007), "The emergence of service operations management as an academic discipline", Journal of Operations Management, 25, pp. 364-374

Davis M. et al, (2005), "Operations Management: Integrating Manufacturing and Services", McGraw-Hill, $5 / e$ 
Hewitt .P, Secretary of State for Trade and Industry, (2002:4), "The Government's Manufacturing Strategy"

Hill T., (2000), "Manufacturing Strategy", Palgrave

Howells J., (2000), “Innovation and Services", UMIST internal publication.

Jick, T (1979) "Mixing qualitative and quantitative methods: triangulation in action", Administrative Science Quarterly, Vol. 24, No. 4, pp. 602-611.

Judd, R.C., (1964), "The case for redefining services," Journal of Marketing, 28, 1, 58-59.

Kellog D. \& Winter N., (1995), " A framework for strategic service management”, International Journal of Production Management, Vol. 13, pp. 323-337

Kotler, P. (1967) "Marketing Management Analysis, Planning and Control", Englewood Cliffs, New Jersey: Prentice-Hall.

Lamming R., (1993), "Beyond partnership - strategies for innovation and lean supply", Prentice Hall International.

Levitt T., (1976), “The Industrialisation of Service", Harvard Business Review, Vol. 54, No. 5, pp. 63 $-74$

Levitt T., (1981), "Marketing intangible products and product intangibles", Harvard Business Review, May/June, pp. $92-104$.

Levitt, T. (1983), "After the sale is over", Harvard Business Review, Vol. 61, No. 5, pp. 87-93

Lewis M. et al, (2004), "Beyond products and Services: opportunities and threats in servitization." IMS Intl. Forum-Italy.

Liker J. (2204), "The Toyota way", McGraw-Hill, New York.

Lovelock C. \& Young R., (1979), "Look to customers to increase productivity", Harvard Business Review, Vol.57, No. 3, pp. $168-178$.

Luiten, H. et al., "Sustainable product service-systems: the Kathalys method". Proceedings of the Second International Symposium on Environmentally conscious design and inverse manufacturing, pp. 190-197

Malleret V., (2006), "Value creation through service offers", European Management Journal, Vol. 24, No. 1, pp. $106-116$

Manzini, E. and Vezolli, C. (2003), "A strategic design approach to develop sustainable product service systems: examples taken from the 'environmentally friendly innovation' Italian prize", Journal of cleaner Cleaner Production, Vol.11, pp. 851-857.

Mathieu V., (2001), "Service strategies within the manufacturing sector: benefits, costs and partnership", International Journal of Service Industry Management, Vol. 12, No. 5, pp. 451-475

Mathieu V., (2001), "Product services: from a service supporting the product to service supporting the client", Journal of Business \& Industrial Marketing, Vol. 16. No.1, pp. 39-58

Maxwell, I. \& van der Vorst, R., (2003), "Developing sustainable products and services", Journal of Cleaner Production, Vol. 11, pp. 883-895. 
Maister D. \& Lovelock C., (1983), "Managing facilitator services", Sloan Management Review, Summer, pp. 19-31

Meijkamp, R. (2000), "Changing consumer behaviour through eco-efficient services. An empirical study of car sharing in the Netherlands", Delft University of Technology,

Meredith, J. (1998), "Building operations management theory through case and field research", Journal of Operations Management, Vol. 16, pp. 441-454

Miles, M.B. \& Huberman, A.M. (1994) Qualitative Data Analysis: $2^{\text {nd }}$ Edition, Thousand Oaks, California: SAGE Publications.

Miller D. et al., (2002), "The problem of solutions: balancing clients and capabilities", Business Horizons, March / April, pp. 3-12

Mills et al., (1996), "A framework for the design of manufacturing process strategies", International Journal of Operations and production Management, Vol.15, No. 4

Morgan, R.M. and Hunt, S.D. (1994), "The Commitment -Trust Theory of Relationship Marketing", Journal of Marketing, Vol. 58, No. 3, pp. 20-38.

Mont O., (2000), "Product Service-Systems", Final Report for IIIEE, Lund University,

Mont, O., (2001), "Introducing and developing a PSS in Sweden", IIIEE Reports 2001:6

Mont, O. and Lindhqvist, T., (2003), "The role of public policy in advancement of product service systems". Journal of Cleaner Production, Vol.11, pp. 905-914.

Morris, B. \& Johnson R., (1987), "Dealing with Inherent Variability: the Difference Between Manufacturing and Service", International Journal of Operations and production Management, Vol. 7, No.4, pp. 13-22.

Mulholland D, 200, "Technology threatens sector's profits, companies need to shift business to service, upgarde sales", Defence News, 7 February

Oliva R. \& Kallenberg R., "Managing the Transition from Products to Services", International Journal of Service Industry Management, Vol.14, No. 2, pp. 1 -10

Oman I.,(2003), "Product Service-Systems and their impacts on sustainable development - a multi-criteria evaluation for Austrian Companies", Frontiers

Oppenheim B., (2004), “Lean Product Development Flow”, Systems Engineering. Vol. 7, No. 4.

Owen D, 1997, "GEC Alstom in career discussions", Financial Times, 19 November.

Patton, M.Q., (2002), Qualitative Research \& Evaluation Methods: $3^{\text {rd }}$ Edition, Thousand Oaks, California: SAGE Publications.

Quinn et al., (1999), "Beyond Products: Services - Based Strategy", Harvard Business Review, March IApril, pp. $58-67$.

Ranky P., (1983), "The Design and Operation of FMS", North-Holland Publishing

Reichard K. et al., (2007), "Integrated management of system health in space applications", Reliability and Maintainability Symposium (RAMS). 
Rothenberg, S., (2007) "Sustainability through Servicizing", MIT Sloan Management Review, Vol. 48, No. 2. pp. 83-91.

Sasser E, (1997), "Match supply and demand in service industries", Harvard Business Review, Nov-Dec, pp. $133-140$

Sawhney M. et al., (2004), "Creating growth with services", MIT Sloan Management Review, Vol. 34, No.4, pp.34-43.

Schmenner, RW (1995), "Service Operations Management", Prentice-Hall, Englewood Cliffs, New Jersey.

Schroeder R., \& Lahr T., 9-(1990), "Development of Manufacturing Strategy - a proven process", Proceedings of the Joint University Conference on Manufacturing Strategy, Michigan.

Shostack G., (1982), "How to design a service", European Journal of Marketing,, Vol.16, No.1, pp. 49-63

Shostack, G.L. (1977) "Breaking Free from Product Marketing",. Journal of Marketing, Vol. 41, No. 2, pp.73-80

Silvestro R. et al., (1992), "Towards a Classification of Service Processes", International Journal of Service Industry Management, Vol. 3, No. 3, pp. 62 - 74.

Silvestro R., (1999), "Positioning service along the volume-variety diagonal", International Journal of Operations and production Management, Vol. 19, No. 4, pp. $399-420$.

Skinner W., (1985), "Manufacturing: The formidable competitive weapon", John Wiley \& sons

Slack N., (2005), "Operations Strategy: "Will it ever realise its potential", Gestao \& Producao, Vol.12, No. 3. pp. $323-332$.

Slack N., (2005), "Patterns of "servitization": Beyond products and services", Institute for Manufacturing, Cambridge, London (CUEA)

Stabell C, \& Fjelstad O, (1998), "Configuring value for competitive advantage: on chains, shops and networks.", Strategic Management Journal, Vol. 19 pp. 413-437

Swamidass P., (2000), Innovations for Competitive Manufacture", Kluwer Academic Publishers.

Taylor, M. D (1936) "Progress in Marketing Research". Journal of Marketing, Vol. 1, No. 1, pp. 56-64.

Thompson, J.D. (1967), "Organizations in Action", McGraw-Hill: New York.

Tukker A., (2004), "Eight Types of Product service system; Eight ways to sustainability? Experiences from SUSPRONET", Business Strategy and the Environment, Vol. 13, pp. 246 - 260

Tukker A \& Tischner U., (2006), "New Business for Old Europe”, Greenleaf Publishing.

Vandermerwe S. \& Rada J., (1988), "Servitization of Business: Adding Value by Adding Services", European Management Journal, Vol.6, No. 4

Vandermerwe S. \& Rada J., (1989), "European Manufacturers Shape Up for Services", Journal of Business Strategy, Nov. / Dec.

Vargo S. \& Lusch R., (2004), "Evolving to a new dominant logic for marketing", Journal of Marketing, Vol. 68, pp. 1-17 
Verstrepen et al., (1999), "Servitization in the automotive sector: creating value and competitive advantage through service after sales" Global Production Management, Kluwer Publishers pp. 538 - 545.

Voss C., (1992), "Applying Service Concepts in Manufacturing", International Journal of Operations and Production Management, Vol. 12, No. 4, pp. 93 - 99.

Voss C., 2003, "Rethinking paradigms of service", International Journal of Operations and production Management,. Vol. 23, No. 1. pp. $88-104$.

Voss, C., Tsikriktsis, N., Frohlich, M. (2002), "Case research in operations management", International Journal of Operations and Production Management, Vol. 22, No. 2, pp. 195-219.

Ward Y. \& Graves A. (2005), "Through-life management: The provision of integrated customer solutions by aerospace manufacturers", Bath University (UK) internal publication

White, A., et al., (1999) Servicizing: The Quiet Transition to Extended Product Responsibility, report from Tellus Institute.

Windahl C. et al., (2004), "Manufacturing firms and integrated solutions: characteristics and implications", European Journal of Innovation Management, Vol.7, No. 3, pp. 218-228

Windahl C. \& Lakemond N., (2006). "Developing integrated solutions: The importance of relationships within the network", Industrial Marketing Management, Vol.35, No.7, pp.806-818

Wise \& Baumgartner. (1999), "Go downstream: The New Profit Imperative in Manufacturing", Harvard Business Review, Sept/Oct., pp. 133 - 141

Womack, J. et al., (1990), "The Machine that Changed the World", Maxwell MacMillan International.

Wong M., (2004), "PSS in the Consumer Goods Industry", Ph D Thesis, Cambridge University.

Yin, R. K. (2003) Case Study Research: Design and Methods, Third Edition. London: Sage Publications. 
Table 1 Exploring categorisation within manufacturing operations

\begin{tabular}{|c|c|c|c|c|c|c|c|c|c|}
\hline & \multicolumn{9}{|c|}{ Source } \\
\hline & $\begin{array}{l}\text { Wheelwright } \\
1978\end{array}$ & $\begin{array}{c}\text { Hayes \& Wheelwright } \\
1984\end{array}$ & $\begin{array}{c}\text { Fine \& Hax } \\
\quad 1984\end{array}$ & $\begin{array}{l}\text { Buffa } \\
1984\end{array}$ & $\begin{array}{c}\text { Cohen \& Lee } \\
1985\end{array}$ & $\begin{array}{l}\text { Hass } \\
1987\end{array}$ & Mills et al. 1995 & $\begin{array}{l}\text { Hill } \\
2000\end{array}$ & Principal Categories \\
\hline \multirow{4}{*}{ 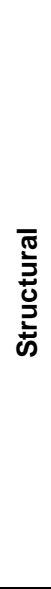 } & Process & Technology & $\begin{array}{l}\text { Technologies \& } \\
\text { Processes }\end{array}$ & $\begin{array}{l}\text { System position, } \\
\text { product \& Process } \\
\text { technology }\end{array}$ & Process & $\begin{array}{c}\text { Process } \\
\text { design }\end{array}$ & Process technology & $\begin{array}{l}\text { Process } \\
\text { flexibility } \\
\text { Process } \\
\text { technology }\end{array}$ & $\begin{array}{l}\text { Process \& } \\
\text { Technology }\end{array}$ \\
\hline & Capacity & Capacity & Capacity & Capacity / location & & & Capacity & $\begin{array}{l}\text { Changes in } \\
\text { capacity } \\
\text { Dominant } \\
\text { Utilization }\end{array}$ & Capacity \\
\hline & Plant & Facilities & Facilities & Facilities & $\begin{array}{l}\text { Facility \& plant } \\
\text { configuration }\end{array}$ & & Facilities, Location & $\begin{array}{c}\text { Capital } \\
\text { investment }\end{array}$ & Facilities \\
\hline & $\begin{array}{c}\text { Vertical } \\
\text { integration, } \\
\text { Supplier control, } \\
\text { Customer control } \\
\text {,Interdependences }\end{array}$ & Vertical integration & Vertical integration, & $\begin{array}{l}\text { Supplier \& Vertical } \\
\text { integration }\end{array}$ & & & Span of process & & Vertical Integration \\
\hline \multirow{8}{*}{ 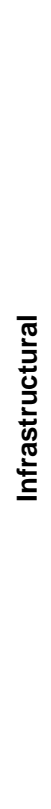 } & & & & & & & & Product range & Product range \\
\hline & Planning \& control & $\begin{array}{l}\text { Production planning, } \\
\text { Material control, } \\
\text { Organisation }\end{array}$ & $\begin{array}{l}\text { Manufacturing } \\
\text { infrastructure }\end{array}$ & Operating decisions & $\begin{array}{l}\text { Control, } \\
\text { Organisation }\end{array}$ & $\begin{array}{l}\text { Information } \\
\text { \& Control } \\
\text { systems }\end{array}$ & Control policies & $\begin{array}{c}\text { Control } \\
\text { Organisation }\end{array}$ & Planning \& Control \\
\hline & Workforce & Workforce & Human resources & $\begin{array}{l}\text { Work force \& job } \\
\text { design }\end{array}$ & $\begin{array}{l}\text { Included in } \\
\text { organisation?? }\end{array}$ & $\begin{array}{l}\text { Organisation } \\
\text { human } \\
\text { resources }\end{array}$ & Human resources & $\begin{array}{l}\text { Direct labour } \\
\& \text { materials }\end{array}$ & Human resources \\
\hline & Quality control & Quality & $\begin{array}{c}\text { Quality } \\
\text { management }\end{array}$ & & $\begin{array}{l}\text { Included in } \\
\text { Product \& Control }\end{array}$ & & Quality & & Quality control \\
\hline & & & $\begin{array}{l}\text { Scope / New } \\
\text { Products }\end{array}$ & & Product & $\begin{array}{c}\text { Product } \\
\text { design, } \\
\text { Research \& } \\
\text { development }\end{array}$ & $\begin{array}{l}\text { New Product } \\
\text { Introduction }\end{array}$ & & $\begin{array}{l}\text { New product } \\
\text { Introduction }\end{array}$ \\
\hline & & & & & & & $\begin{array}{l}\text { Performance } \\
\text { measurement }\end{array}$ & & $\begin{array}{l}\text { Performance } \\
\text { measurement }\end{array}$ \\
\hline & & & Vendor relations & & & $\begin{array}{l}\text { Supplier } \\
\text { roles \& } \\
\text { relationships }\end{array}$ & Suppliers & & Supplier relations \\
\hline & & & & & & & & & Customer relations \\
\hline
\end{tabular}


$\underline{\text { Table } 2 \text { Framework for production, product-centric servitized and service operations }}$

\begin{tabular}{|c|c|c|c|c|}
\hline \multirow{2}{*}{\multicolumn{2}{|c|}{ Characteristics }} & \multicolumn{3}{|c|}{ Type of operations } \\
\hline & & Product Focussed Operations & Product-centric Servitized Operations & Services Focussed Operations \\
\hline \multirow{6}{*}{ 范 } & Unit of Analysis & $S B U$ & $S B U$ & $S B U$ \\
\hline & $\begin{array}{l}\text { Type of company being } \\
\text { considered }\end{array}$ & $\begin{array}{c}\text { Larger and somewhat conventional volume } \\
\text { production }\end{array}$ & Product sold with platform of bespoke services & Larger and somewhat conventional services \\
\hline & $\begin{array}{l}\text { Examples of associated } \\
\text { products and services }\end{array}$ & Bosch, Goodrich, Smiths Medical & $\begin{array}{l}\text { Lexus, Rolls-Royce (TotalCare), Toshiba } \\
\text { Medical }\end{array}$ & Hertz, Easyjet, BUPA \\
\hline & Principal delivery system & Product focused delivery system & Integrated product and service delivery system & Services focused delivery system \\
\hline & Nature of the delivery system & $\begin{array}{l}\text { Tends towards physical transformation of } \\
\text { materials into tangible goods }\end{array}$ & $\begin{array}{l}\text { Tends towards physical transformation of } \\
\text { materials into tangible assets, sold along with } \\
\text { support services, to deliver functional capability } \\
\text { to the customer }\end{array}$ & $\begin{array}{l}\text { Tends towards creating experiential } \\
\text { transformation through facilitation and mediation }\end{array}$ \\
\hline & $\begin{array}{l}\text { Typical scope and capabilities } \\
\text { of the delivery system }\end{array}$ & $\begin{array}{l}\text { Design, development, procurement, } \\
\text { production, test and distribution }\end{array}$ & $\begin{array}{l}\text { Design, development, production, test, } \\
\text { monitoring, maintenance, repair refurbishment, } \\
\text { upgrading, and disposal }\end{array}$ & $\begin{array}{l}\text { Design, co-development, delivery, facilitation } \\
\text { and evaluation. }\end{array}$ \\
\hline \multirow{4}{*}{ 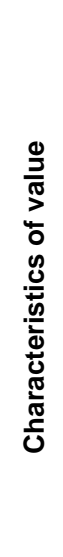 } & $\begin{array}{l}\text { Business model: how the } \\
\text { company tends to do } \\
\text { business }\end{array}$ & $\begin{array}{l}\text { Tends towards transactional based: } \\
\text { Focusing on producing and selling material } \\
\text { artefacts. }\end{array}$ & $\begin{array}{l}\text { Tends to be based on a blend of transactional } \\
\text { and relationship: } \\
\text { Focusing on providing an integrated product and } \\
\text { service offering that delivers value in use. }\end{array}$ & $\begin{array}{l}\text { Tend towards relationship based: } \\
\text { Focusing on delivery of services. }\end{array}$ \\
\hline & $\begin{array}{l}\text { Value Proposition: what the } \\
\text { customer tends to value }\end{array}$ & Tends to focus on the ownership of an artefact & $\begin{array}{l}\text { Tends to focus on product availability, } \\
\text { performance, along with risk and reward sharing. }\end{array}$ & $\begin{array}{l}\text { Tends to focus on the delivery of functional } \\
\text { result. }\end{array}$ \\
\hline & $\begin{array}{l}\text { Order winning criteria of the } \\
\text { customer }\end{array}$ & $\begin{array}{l}\text { Features of product } \\
\text { Purchase cost of product } \\
\text { Specification and Quality conformance } \\
\text { Delivery of product }\end{array}$ & $\begin{array}{l}\text { Features of product and service } \\
\text { Total cost of ownership } \\
\text { Availability of product and capacity to deliver } \\
\text { services }\end{array}$ & $\begin{array}{l}\text { Features of services } \\
\text { Cost of services } \\
\text { Quality conformance of services } \\
\text { Delivery of services }\end{array}$ \\
\hline & $\begin{array}{l}\text { Typical value metrics for the } \\
\text { internal delivery systems }\end{array}$ & $\begin{array}{l}\text { Cost of production } \\
\text { Product conformance } \\
\text { Delivery performance }\end{array}$ & $\begin{array}{l}\text { Product life-cycle costs } \\
\text { Product conformance and service delivery } \\
\text { System responsiveness }\end{array}$ & $\begin{array}{l}\text { Cost of service delivery } \\
\text { Conformance to customer requirements } \\
\text { Availability and service delivery performance }\end{array}$ \\
\hline
\end{tabular}




\begin{tabular}{|c|c|c|c|c|c|}
\hline \multirow{12}{*}{ 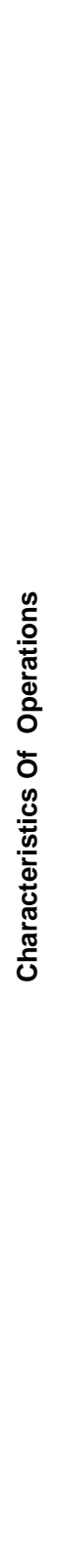 } & \multirow{5}{*}{ 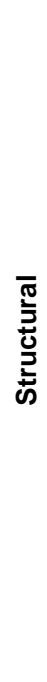 } & 1. Process \& Technology & $\begin{array}{l}\text { Tend to exploit automation to deliver high } \\
\text { levels of product conformance and volume } \\
\text { with minimal worker intervention. }\end{array}$ & $\begin{array}{l}\text { Tend to exploit a range of technologies, } \\
\text { throughout operations, to achieve efficiency in } \\
\text { production and effectiveness in service delivery. }\end{array}$ & $\begin{array}{l}\text { Tend to exploit largely information technologies, } \\
\text { such as databases and Integrated } \\
\text { communications, to enhance customer } \\
\text { interaction. }\end{array}$ \\
\hline & & 2. Capacity & $\begin{array}{l}\text { Tend to match capacity to demand, controlling } \\
\text { and balancing, in order to maximise utilisation } \\
\text { of expensive resources }\end{array}$ & $\begin{array}{l}\text { Tend to experience varying demand signals at } \\
\text { multiple customer 'touch points' and so need to } \\
\text { operate with differing levels of capacity } \\
\text { utilisation. }\end{array}$ & $\begin{array}{l}\text { Tend to accommodate fluctuations in demand by } \\
\text { running at lower levels of capacity utilisation }\end{array}$ \\
\hline & & 3. Facilities & $\begin{array}{l}\text { Tend to be large factories, arranged around } \\
\text { similar product to exploit economies of scale, } \\
\text { and often located to exploit resource } \\
\text { availability. }\end{array}$ & $\begin{array}{l}\text { Tend to combine both centralised manufacture, } \\
\text { but mainly focusing on product final assembly } \\
\text { and test, along with multiple field facilities for } \\
\text { maintenance and repair located close to market }\end{array}$ & $\begin{array}{l}\text { Tend to be smaller, multiple facilities, that are } \\
\text { client friendly, located close to market, and help } \\
\text { to impress and reinforce relationships }\end{array}$ \\
\hline & & 4. Supply Chain Positioning & $\begin{array}{l}\text { Tend to be vertically integrated where such } \\
\text { control can help to maximise quality } \\
\text { conformance and minimise cost. }\end{array}$ & $\begin{array}{l}\text { Tend to retain vertical integration in product } \\
\text { manufacture and a range of closely integrated } \\
\text { partners to deliver services. }\end{array}$ & $\begin{array}{l}\text { Tend to focus on only the brokerage of } \\
\text { knowledge and capacity necessary to respond to } \\
\text { customer requirements }\end{array}$ \\
\hline & & 5. Planning and Control & $\begin{array}{l}\text { Tend to focus on replenishment systems, } \\
\text { sometimes large and complex, that minimise } \\
\text { stock holding costs }\end{array}$ & $\begin{array}{l}\text { Tend to focus on the optimisation of product } \\
\text { availability }\end{array}$ & $\begin{array}{l}\text { Tend to rely on project management techniques } \\
\text { and individuals themselves to provide } \\
\text { responsive service to customer. }\end{array}$ \\
\hline & \multirow{7}{*}{ 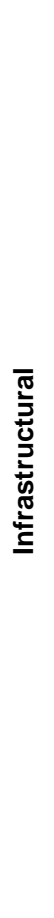 } & 6. Human Resources & $\begin{array}{l}\text { Tend to use lower skilled workers through } \\
\text { minimisation of intervention and well defined } \\
\text { production routines }\end{array}$ & $\begin{array}{l}\text { Tend to need workers with high levels of product } \\
\text { knowledge and relationship development } \\
\text { capability }\end{array}$ & $\begin{array}{l}\text { Tend to be highly skilled workers with } \\
\text { particularly good communication skills with } \\
\text { which to demonstrate value to customer }\end{array}$ \\
\hline & & 7. Quality Control & $\begin{array}{l}\text { Tend to have systems that measure and } \\
\text { monitor quality conformance throughout } \\
\text { production in order to minimise scrap materials } \\
\text { and components. }\end{array}$ & $\begin{array}{l}\text { Tend to use product assurance methods } \\
\text { combined with customer satisfaction } \\
\text { assessments }\end{array}$ & $\begin{array}{l}\text { Tend to rely on individuals developing } \\
\text { acceptability criteria and judging performance } \\
\text { against these. }\end{array}$ \\
\hline & & 8. Product / service range & $\begin{array}{l}\text { Tend to vary in size, though smaller product } \\
\text { ranges are preferred to help maximise } \\
\text { production efficiencies }\end{array}$ & $\begin{array}{l}\text { Tend have limited range combined with 'bundles' } \\
\text { of supporting services. }\end{array}$ & $\begin{array}{l}\text { Tend to vary in size, though smaller ranges of } \\
\text { services are preferred to help maximise delivery } \\
\text { efficiencies }\end{array}$ \\
\hline & & $\begin{array}{l}\text { 9. New product / service } \\
\text { Introduction }\end{array}$ & $\begin{array}{l}\text { Tend to use centralised capabilities to fully } \\
\text { design and test new products, prior to their } \\
\text { entry into production, in order to minimise in- } \\
\text { market 'disturbances.' }\end{array}$ & $\begin{array}{l}\text { Tend to used centralised capabilities for product } \\
\text { design, taking particular account of maintenance } \\
\text { and repair, and that complement services co- } \\
\text { created with the customer. }\end{array}$ & $\begin{array}{l}\text { Tend to be co-created, tested and refined, with } \\
\text { customers in the field. }\end{array}$ \\
\hline & & $\begin{array}{l}\text { 10. Performance } \\
\text { Measurement }\end{array}$ & $\begin{array}{l}\text { Tend to use parameters such as - 'to } \\
\text { specification', 'to cost' and ,'on time' delivery. }\end{array}$ & $\begin{array}{l}\text { Tend to use product availability, response time } \\
\text { and customer satisfaction }\end{array}$ & Tend to use customer satisfaction metrics \\
\hline & & 11. Supplier relations & $\begin{array}{l}\text { Tend to apply direct and forcefully leverage to } \\
\text { suppliers to minimise input costs }\end{array}$ & $\begin{array}{l}\text { Tend to integrate internal and external supply } \\
\text { chains into the delivery process to achieve cost } \\
\text { effective flexibility in supply }\end{array}$ & $\begin{array}{l}\text { Tend to expect same level of responsiveness } \\
\text { and commitment from suppliers as they would } \\
\text { give to their own customers }\end{array}$ \\
\hline & & 12. Customer relations & $\begin{array}{l}\text { Tend to have limited interaction with } \\
\text { customers choosing, instead, to invest } \\
\text { energies internally to improve efficiencies }\end{array}$ & $\begin{array}{l}\text { Tend to have strong interaction with customers } \\
\text { through relationships based on product } \\
\text { availability and performance }\end{array}$ & $\begin{array}{l}\text { Tend to invest heavily in developing and } \\
\text { maintain relationships with customers }\end{array}$ \\
\hline
\end{tabular}


Figure 1 PSS Classifications (Tukker 2004)

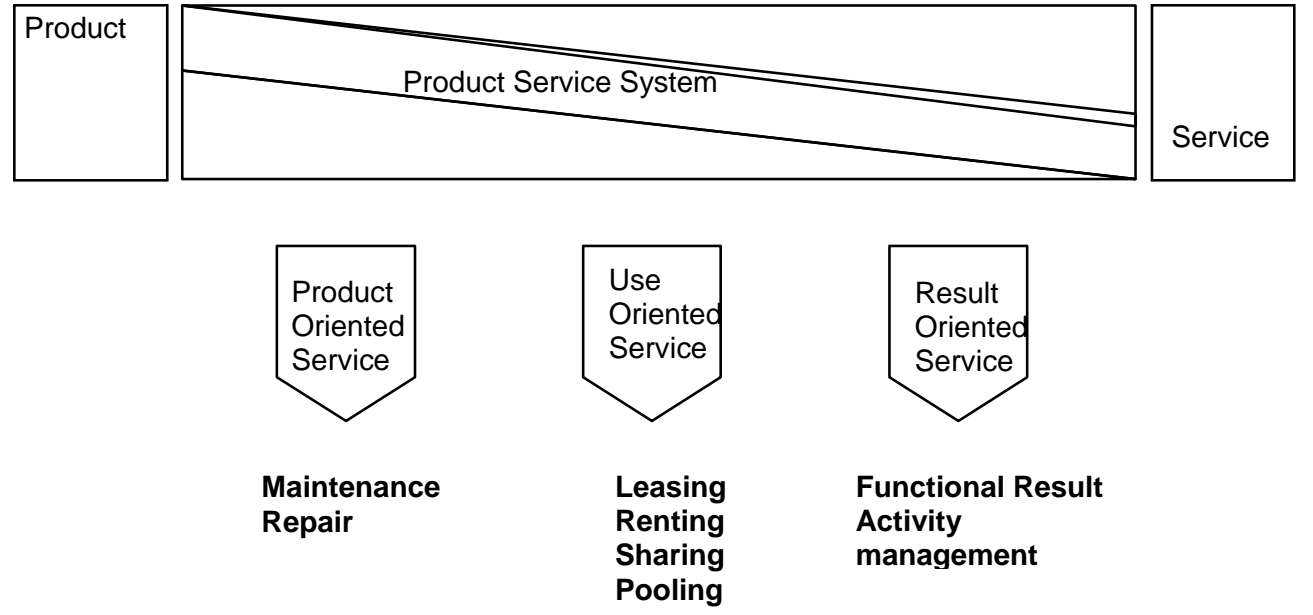

